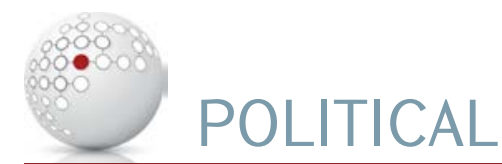

SCIENCE

\author{
ARESTAKES SIMAVORYAN \\ Research Fellow, National Archives of Armenia \\ (1) https://orcid.org/0000-0002-7519-5127 \\ VARDAN ATOYAN \\ Doctor of Sciences (Political Science), \\ Head of Social Sciences Department, \\ Armenian State University of Economics \\ (D) https://orcid.org/0000-0002-4974-0312
}

SOSE SIMAVORYAN

BA Student of the Department of International Relations and Development, LCC International University

(Klaipèda, Lithuania)

https://orcid.org/0000-0003-1028-9162

\title{
ROLE OF TURKISH THINK TANKS IN THE STATE-DIASPORA RELATIONS: THE CASE OF SETA AND ORSAM
}

This paper provides a comprehensive framework to explain the policies Turkish think tanks have adopted for the development of Turkey-Turkish diaspora relationship in recent years. The purpose of this research is to identify the involvement and role of two of Turkey's leading think tanks, SETA and ORSAM, in state-diaspora relations. The sources of research are official statements and documents, academic publications and news sources. The research revealed that Turkey's Diaspora policy is the result of a combination of domestic (governmental) and strategic actions. Domestically, the Justice and Development Party's rise to power resulted in drastic political reforms and the promotion of the role of the Diaspora in domestic activities. Strategically, in recent years as the influence of think tanks in the Turkish domestic politics rose, they started to shape 
new Diaspora agendas. However, the research has shown that as the Turkish think tanks are relatively new actors in contemporary Turkish politics, they are still unable to play major roles in big political sectors such as the Diaspora. The research also showed that the type of the think tank also affects the level of independence and, therefore, the effect the think tank has on the issues concerning the Diaspora. Summing up the observation of some features of the Diaspora's policy and the work done in a number of areas, the authors infer that the institutions involved in it are of a horizontal nature.

Keywords: think tanks, Turkey, Turkish diaspora, public diplomacy, SETA, ORSAM JEL: J24, Z00

DOI: 10.52174/1829-0280_2021_5_143

Introduction. The globalization that has been growing in the past decades has been expanding and increasing the length and intensity of economic, cultural and financial ties throughout the world. We live in a space of migratory flows of people; the world is becoming more and more united. Mankind has entered an extremely difficult era of its existence when the world is simultaneously integrating and disintegrating, globalizing and localizing, uniting and separating.

Great transformations encompassing all the spheres of life, in which overall integration and unprecedented development of the information sphere are the objective preconditions for both consolidation and separation of humanity's spiritual and material potential. ${ }^{1}$

It is noticeable that from the second half of the $20^{\text {th }}$ century, migration processes have taken on a truly global scale, encompassing all the continents of our planet, social strata and groups of society, influencing various spheres of social life. It is, therefore, no surprise why calling the past century as the "era of migration" is entirely legitimate. ${ }^{2}$ Nowadays, social transformation and development have a certain dependence on migration everywhere in the world.

The cultural boundaries of modern Turkey have long gone beyond the borders of the official state. A significant number of Turks live in Europe, the United States, the Middle East, and North Africa. A lot of major changes have happened with the migration dynamics of Turkey over the past 60 years, thus creating the vast Diaspora of around 5 million people. Nowadays Turkish polices towards the Diaspora are not focused on financial engagement, but on the Diaspora's integration on benefiting Turkey's image and political claims. ${ }^{3}$

In the political scene, think tanks appear to be a relatively new type of actors. The think tank is a self-sufficient institution that produces mostly interdisciplinary intellectual products, provides consulting, educational services and bridges the gap between the political elite, the academic community, and society, aiming to increase its influence in political processes and to contribute to

\footnotetext{
1 Atoyan, V. (2014). Globalization and Transformation of the Nation State. In International conference on arts, economics and management (ICAEM'14), March 22-23, 2014, Dubai (UAE), 7982. http://dx.doi.org/10.15242/ICEHM.ED0314041

2 Gehrke, L., Pluim, M. (2017). The era of migration - the next 25 years. https://www.icmpd.org/news-centre/news-detail/the-era-of-migration-the-next-25-years-by-lukasgehrke-and-martijn-pluim/. (accessed August 1, 2021).

3 Bilgili, O., Siegel, M. (2011). Understanding the changing role of the Turkish diaspora. http://collections.unu.edu/eserv/UNU:209/wp2011-039.pdf. (accessed August 5, 2021).
} 
the resolution of problems of the individual, society, state or of global importance in accordance with its own values, ideological guidelines. ${ }^{4}$

Taking into consideration their influence on the socio-political, economic and geopolitical development, think tanks are considered as the "fifth power" after media. ${ }^{5}$ Turkey did not stand behind these processes, and the role of think tanks in both domestic and foreign policy of the country has grown dramatically in recent years.

The first think tank activity of which is examined in this paper is Foundation for Political, Economic and Social Research (Siyaset, Ekonomi ve Toplum Araştirmalar Vakfi), or SETA. The Foundation was founded in 2006 based on the Ankara Center for Political Studies, by the spokesman of Turkish President Recep Tayyip Erdoğan. It is a quasi-governmental, Islamic-conservative orientated think tank. One of the privileges this think tank has is its branches in Washington, D.C. and Berlin. In recent years, the focus of the Center's research is on the media, education, human rights, the Turkish diaspora, security, defense, and technology.

The second think tank whose activity will be examined throughout this research is the Center for Middle Eastern Studies (Ortadoğu Araştirmalari Merkezi), or ORSAM. The think tank was established in 2009 as a result of reunification with the Institute of Global Strategy and acts as a non-governmental organization. The main purpose of the center is to examine the conflicts in the Middle East, the political trends in the region, and their impact on Turkey. It has close relations with former Turkish President Abdullah Gul. Unlike SETA, this think tank is funded by several Turkmen foundations in the Middle East. Financial sources also come from donations, magazine sales, and advertising, therefore, showing that the activity of the given think tank is more or less independent of the Government.

Literature Review. There are quite a lot of academic publications about the Turkish diaspora where the authors address various aspects of the problem. The works studied within the framework of the paper particularly refer to the StateDiaspora relations (spheres of cooperation), the financial, economic, and scientific potential of the Diaspora.

Thus, although the authors Ksendzik ${ }^{6}$ and Chulkovskaya ${ }^{7}$ point out in their studies that the problems of foreign communities in Turkey have been in the spotlight since the 1970s, nevertheless, Bayrakli, the director of the European Studies Department of the Political, Economic and Social Research Foundation,

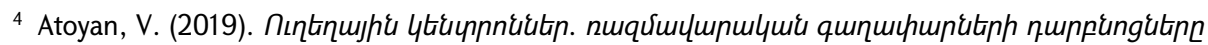
(Think tanks: The smithies of strategic ideas). Yerevan, Zangak publishing house, 216. https://ssrn.com/abstract=3856159

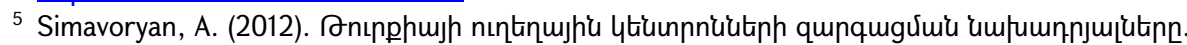
ujdútumlumu fu'unthnutinn (Preconditions of the development of think tanks in Turkey: Modern

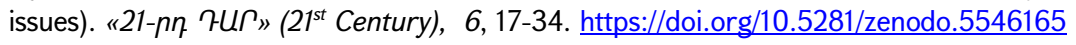

${ }^{6}$ Ksendzik, N. (1991). Турецкая трудовая иммиграция в странах Западной Европы (70-80-е г2.) (Turkish labor immigration in Western Europe (70-80s)). Kiev.

7 Chulkovskaya, E. (2014). Турецкая диаспора Германии: между Анкарой и Берлином (Turkish diaspora in Germany: between Ankara and Berlin). Moscow. Middle East Institute. 
who is close to Turkey's ruling AKP, said: "Turkey has long been indifferent to the problems of Turks living abroad and has not developed a policy (strategy) towards the Diaspora". ${ }^{8}$

According to Baser, especially after the Justice and Development Party came to power, the role of the Turkish diaspora as a "soft force" supporting public diplomacy was used in the background of the economic, political and ideological changes that took place in the country. ${ }^{9}$ On the one hand, a policy of establishing and developing stable relations with the Diaspora was implemented. ${ }^{10}$ On the other hand, the strengthening of these ties laid the foundations for the process of capitalizing the existing economic ${ }^{11}$ and scientific potential. ${ }^{12}$

There are a lot of publications on the activity of Turkish think tanks in public policy. According to experts Kizyukov, ${ }^{13}$ Aydin ${ }^{14}$ Toktaş and Aras ${ }^{15}$ the

${ }^{8}$ Bayrakli, E. (2016). Diaspora Politikamiz (Our Diaspora policy). https://www.setav.org/diasporapolitikamizl. (accessed June 17, 2021).

9 Baser, B. (2017). Turkey's diaspora engagement policy under the Justice and Development Party. International Migration Institute Network Blog.

https://www. migrationinstitute.org/blog/turkey2019s-diaspora-engagement-policy-under-the-justiceand-development-party (accessed August 17, 2021).

${ }^{10}$ See Baser, B. (2017). Turkey's diaspora engagement policy under the Justice and Development Party. International migration institute network blog.

https://www.migrationinstitute.org/blog/turkey2019s-diaspora-engagement-policy-under-the-justiceand-development-party (accessed August 17, 2021); Chulkovskaya E. (2014). Турецкая диаспора Германии: между Анкарой и Берлином (Turkish diaspora in Germany: between Ankara and Berlin). Moscow. Middle East Institute; Bibikova O. (2014). Турецкие иммигранты в Германии: проблемы и перспективы (Turkish immigrants in Germany: problems and prospects). Россия и мусульманский мир (Russia and the Moslem world), 9(267), 168-187.

${ }^{11}$ See Kalça, A., Durmaz, A. (2010). Outside the homeland of the Turks economic potential of the Diaspora. 2nd international symposium on sustainable development, June 8-9, 2010, Sarajevo (Bosnia and Herzegovina). https://omeka.ibu.edu.ba/files/original/252225c345f542fb52d0e4b3a4bb26e9.pdf (accessed July 15, 2021); Hurriyet Daily News. (2012). Council mobilizing the Turkish diaspora. https://www.hurriyetdailynews.com/council-mobilizing-the-turkish-diaspora-30022 (accessed August 25, 2021); DEIK. (2016). 2 Dünya Türk Iş Konseyi Dünya Türk Girişimciler Kurultayi (2 World Turkish Business Council World Turkish Entrepreneurs Congress). https://www.deik.org.tr/uploads/dtik-sonuc-raporu 11-4-2016.pdf (accessed August 5, 2021); TOBB. (2014). Türk Diasporasi “Dünya Şehir Aği” kuruyor (The Turkish diaspora is establishing a "world city network"). https://tobb.org.tr/Sayfalar/Detay.php?rid=19696\&/st=MansetListesi (accessed August 30, 2021).

12 See Uygun, A. (2012). Yurt Dișindaki Türk Bilim İnsanlari Kurultayi ilk kez İstanbul'da yapildi. Telepati E-dergisi, Ağustos, 203 (The congress of Turkish scientists abroad was held in Istanbul for the first time. "Telepati", E-journal. 203); Arslan, N. (2017). Beyin Göçü ve Diaspora Ağlari (Brain drain and diaspora networks). Sosyal Siyaset Konferanslari Dergisi (Journal of Social Policy Conferences), 73, 1-33; Akkuş, Ö., Durmaz, A. (2021). Tersine Göç Eğiliminin Akademik

Diasporanin Verimliliği Üzerindeki Etkisi: Almanya Örneği (The effect of reverse migration tendency on the productivity of academic diaspora: the case of Germany). Uluslararasi Ekonomi ve Yenilik Dergisi (International journal of economics and innovation), 7(2), 259-276. https://doi.org/10.20979/ueyd.917786

${ }^{13}$ Kizyukov, S. (2006). Внешнеполитические концепции республиканской Турции (Foreign policy concepts of Republican Turkey). Bishkek.

${ }^{14}$ Aydin, A. (2006). The genesis of think-tank culture in Turkey: past, present and future? (Master's thesis). Middle East Technical University. Ankara.

15 Toktaş, Ş., Aras, B. (2012). National security culture in Turkey: A qualitative study on think tanks. Bilig, 61, 245-264. 
development and significance of think tanks in Turkish public and political life, particularly in relations with the outside world, in matters of economy and security, coincided with major regional and geostrategic turning points.

According to researchers Outzen, Schwing, ${ }^{16}$ and Simavoryan ${ }^{17}$ several dozen think tanks have been set up since the Justice and Development Party came to power. The vast majority of them operate in the private sector, attached to university-academic, state structures, and, a small part, to parties. ${ }^{18}$

Researchers Suleimanov, ${ }^{19}$ Avatkov, Vidyaykin, ${ }^{20}$ and Simavoryan ${ }^{21}$ point out that Turkey's think tanks, as new actors in foreign policy, are partly contributing to the development and strengthening of Turkey's diplomatic efforts. Researcher Karpuzcu has also referred to the influence of these two think tanks on the development of Turkish foreign policy as a separate case. His research shows a consistent connection between these think tanks' publications and speeches of political decision makers. The author states in his research that ORSAM is especially influential in terms of persuading policy makers of Turkish-Russian relations, and SETA in terms of Turkish-Russian and Turkish-American relations. ${ }^{22}$

As for the participation and activities of the Turkish think tanks in the Turkey-Turkish diaspora relations, the authors of the publications we studied did not refer to it as a special case.

Research Methodology. The starting point for the study was ORSAM and SETA's activities in the field of State-Diaspora cooperation over the past decade. The activity of aforementioned Turkish think tanks and the work of the relevant bodies responsible for relations with the Turkish diaspora, served as a methodological basis for the study of the topic, showing the extent to which these institutions influence Turkey-Diaspora relations.

${ }^{16}$ Outzen, R.H., Schwing, R. (2016). Supporting Democracy in Erdogan's Turkey: The role of think tanks. In Strategic forum. 292, 1-15. National Defense University Press.

${ }^{17}$ Simavoryan, A. (2015). Strategic Research Centers in Turkey. “Globus” Analytical Bulletin, 5, 13-21. https://doi.org/10.5281/zenodo.5572698

${ }^{18}$ See Aydin, A. (2006). The genesis of think-tank culture in Turkey: past, present and future? (Master's thesis). Middle East Technical University. Ankara; Karabulut, N. (2019). Impact Capacity of Think Tanks in Turkey (Master's thesis). Necmettin Erbakan University. Konya; Babur, M. (2021). Bir Temsil Alani Olarak Türkiye'de Düşünce Kuruluşlari (Turkey's think tanks as a sphere of representation). Afyon Kocatepe Üniversitesi Sosyal Bilimler Dergisi (Afyon Kocatepe University Journal of Social Sciences), 23(1), 1-19.

${ }^{19}$ Suleimanov, А. (2010). Центры стратегических исследований внешней политики Турецкой Республики: общая характеристика и этапы функционирования (The centers of strategic research of foreign policy of Turkish Republic: The general characteristic and stages of functioning). Bестник РУДН. Серия: Политология (RUDN Journal of Political Science), 4, 61-67.

${ }^{20}$ Avatkov, V., Vidyaykin, А. (2013). Деятельность аналитических центров в Турции при правлении Партии справедливости и развития (Think tanks in Turkey in the era of JDP). Вестник МГИМО (MGIMO Review of International Relations), 3, 100-104.

${ }^{21}$ Simavoryan, A. (2015). Strategic Research Centers in Turkey. "Globus” Analytical Bulletin, 5, 13-21. https://doi.org/10.5281/zenodo.5572698

${ }^{22}$ Karpuzcu, T. (2018). L'influence des elites de think-tank sur la formation de la politique exterieure de la Turquie entre 2010-2016 (The influence of think-tank elites on the formation of Turkey's foreign policy between 2010-2016). Universite Yeditepe, 119. 
In this regard, the institutional and qualitative research methods were mostly used by the authors to achieve their research goals. While writing the paper, heuristic and descriptive methods were used for better illuminating the case study presented in the research. In order to provide a comprehensive analysis of the issue, in particular to outline the impact of ORSAM and SETA on those processes, open source information on the events organized by these think tanks and their publications on the issues of the Turkish diaspora were examined. The academic publications of many other authors dedicated to the Turkish diaspora and the activities of Turkish think tanks were also considered.

It is noteworthy that the development and implementation of a coordinated policy towards the Diaspora presupposes the creation and implementation of cooperative effective mechanisms for the management of educational, cultural, social, political and scientific processes. In the context of the above, the choice to study the role of ORSAM and SETA in the Turkey-Turkish diaspora relations among hundreds of Turkish think tanks is not accidental. It is conditioned by the fact that these think tanks have a certain role in the toolkit of the policy towards the Diaspora, they are noticeably involved in that process, they apply such mechanisms, which are reflected in the strategic programs of the Turkish government.

It should be noted that although the two above-mentioned think tanks were selected as the main object of our study, in order to fully assess the developments in the field of State-Diaspora cooperation, some reference was made to the activities of other institutions. In particular, some of the reports of the Turkish Asian Center for Strategic Studies (TASAM), a conference on cooperation between the Diaspora of Turkic-speaking countries, and the vision for cooperation were observed. These help to outline the functional significance and level of integration of the Turkish diaspora in Turkish state policy.

Discussion. In the field of international relations, the Turkish diaspora has acquired an important role as a particle of nation's diplomacy, turning it into a unique entity. The complicated and globalized geopolitical, economic situation in the world forces different states to pursue more active policies in relations with Turkish diaspora. Turkey also did not remain indifferent to these policies. This is the reflection of the economic, political and ideological change in the country after the Justice and Development Party came into power. It highlighted the role of the Turkish diaspora as a "soft power" supporting public diplomacy. On the one hand, the policy of establishing and developing a stable relationship with the Turkish diaspora was implemented. On the other hand, the reinforcement of these ties gave the opportunity to put the foundation of the process of capitalization of the political, economic and scientific potential there. Now the term "diaspora" has a different meaning in Turkey. In essence, this is related to the change of the Turkish government's approach and policy towards its Diaspora. "Turkey's new directorate has been working vigorously to create, organize and activate its Diaspora. Workshops are being organized all around 
Europe, and attempts are being made to merge Turkish and Azeri diaspora organizations under certain umbrella federations". ${ }^{23}$

Despite the fact that the first think tanks emerged in Turkey in the 60s of the last century, the sector experienced an upsurge in the ruling of the Justice and Development Party. More than 80 research organizations have been established in Turkey in the last decade, and the total number exceeds $150 .{ }^{24}$ Many of them are partner organizations of political parties and universities; some are independent while others are funded by the Government.

In order to understand why and how an urge has occurred to include the activities of Turkish think tanks into the foreign policy making and specifically to strengthening ties between the Turkish state and its Diaspora, we need to look back into the history of Turkish migration. Under the 1961 Constitution, Turkish citizens received a legal right to freely enter and leave the country. Since that time, the mass migration of the Turkish workforce to the developed states of Western Europe began, which gradually became one of the factors influencing the socio-economic situation in the country. Interestingly, in the 60-70s, foreign currency transfers of Turkish citizens from abroad were the main source of foreign currency inflows to the country, which affected the improvement of the balance of payments of Turkey. ${ }^{25}$ Foreign migrant transfers have long helped the Turkish government to balance the balance of payments and replenish Government reserves in foreign currencies. ${ }^{26}$ However, the amount of foreign transfers began to decline significantly in recent years, and the Diaspora stopped being an economic power advantage for the Turkish Republic. Therefore, the Turkish government has decided to use its Diaspora not as a "currency wallet" but as intellectual power that is one of the key preconditions for reaching to “New Turkey” promised by president Recep Tayyip Erdoğan.

Think tanks are a relatively new factor in Turkey's policy towards its Diaspora but during this short period of time they have gained significant importance in the Government's plans of action. This shows that the Turkish government implements the Advocacy Coalition Framework theory, suggested by Paul Sabatier and Hank Jenkins-Smith, according to which political changes happen through the coordinate activity of parties sharing the same interests. ${ }^{27}$

SETA started its activity towards professionals' repatriation recently. In 2015, SETA was involved in a project implemented by the Turkish State

${ }^{23}$ Baser, B. (2017). Turkey's diaspora engagement policy under the Justice and Development Party. International migration institute network blog. https://www.migrationinstitute.org/blog/turkey2019sdiaspora-engagement-policy-under-the-justice-and-development-party (accessed August 17, 2021).

${ }^{24}$ Simavoryan, A. (2015). Strategic research centers in Turkey. "Globus" analytical bulletin, 5, 13-21. https://doi.org/10.5281/zenodo.5572698

${ }_{25}$ Masumova, N. (2009). Миграция турецкой рабочей силы в страны Западной Европы (Turkish Labor Migration to Western Europe). Мировое и национальное хозяйство (World and national economy), 2(9), 55-67.

${ }^{26}$ Erder, S. (2002). Новые тенденции международной миграции в Турции (New trends in international migration in Turkey). http://www.demoscope.ru/weekly/2002/079/analit04.php. (accessed June 28, 2021).

${ }^{27}$ Mendizabal, E. (2017). How change happens and what can think tanks do about it? https://onthinktanks.org/articles/how-change-happens-and-what-can-think-tanks-do-about-it/. (accessed August 28, 2021). 
Department for Coordinating the Activities of Diaspora and The Office of Foreign Turks and Friendly Societies (YTB) called "Brain Center Cooperation". The main goal of the project is to set up good economic, political relations between Turkey and its Diaspora. ${ }^{28}$ According to the project, the Turkish diaspora has vital importance for Turkey and even for the Turkic world, therefore looking from a structural point of view, it is necessary to recognize the Diaspora's members to be more integrated into the society of the country they belong to. Thus, they can contribute to the solution of Turkey's regional and global issues. ${ }^{29}$ In recent years, SETA took part in two projects organized by "The Brain Center Cooperation".

In June 2015, for the first time, YTB hosted a think tank conference in Ankara. With support from SETA, round table meetings were organized with think tanks in the Balkans. Representatives of think tanks in many Balkan countries, including Albania, Serbia, Greece, Bosnia and Herzegovina, Macedonia, Kosovo, and Croatia, arrived in Ankara ${ }^{30}$. The main purpose of the meetings was to re-establish contact with the Balkan countries and the Turkish community there. This would soon be an important link for the return of Turkish specialists from the Balkan countries. The 2-day workshop of the aforementioned think tanks in Kosovo on November 3, 2016, states the success of the former gathering. 31

In addition to promoting professional repatriation in collaboration with foreign think tanks, SETA, in partnership with YTB, is organizing Turkish language courses abroad. ${ }^{32}$ Thus, the think tank is trying to exert "soft power" on young compatriots living abroad, awakening in them love for homeland and thoughts of returning home.

The information above shows that although SETA has joined the Government's professional repatriation policy quite late, it has been able to support the program as much as possible. However, it is noteworthy to mention that YTB, which is a state body under the auspices of the Government, partnered all scientific repatriation programs organized by the think tank. This shows that the think tank is still unable to operate independently on the issues related to the Diaspora.

As another attempt to integrate the Diaspora into its internal policies, the Turkish government implemented legislative changes that allowed Turkish migrants with no Turkish citizenship to obtain "blue cards". This allowed migrants to enjoy almost all of the rights granted to them, as Turkish citizens. In

\footnotetext{
${ }^{28}$ Simavoryan, A. (2019). On some of the issues of expertise centers in Turkey. Orbeli Center. http://dx.doi.org/10.2139/ssrn.3891456

${ }^{29}$ TASAM. (2016). 5th World Turkic Forum. Strategic Communication: Reference Values, Institutions. https://tasam.org/Files/Etkinlik/File/VizyonBelgesi/DTF5 Vizyon TR pdf 0ba46c0f-5d28-4d14-b18b83aafOf1294f.pdf. (accessed August 27, 2021).

30 YTB. (2015). https://www.ytb.gov.tr/haberler/balkan-dusunce-kuruluslari-ankarada-bulustu. (accessed August 8, 2021).

31 YTB. (2016). https://www.ytb.gov.tr/haberler/balkan-dusunce-kuruluslari-kosovada-bulustu. (accessed August 15, 2021).

32 YTB. Turkish and Education. https://www.ytb.gov.tr/en/abroad-citizens/turkish-and-education. (accessed August 22, 2021).
} 
July 2016, a new law on the foreign workforce was also adopted, enabling highly qualified foreign nationals and Turks living in the Diaspora to work in Turkey in the fields of science and technology, medicine, sports, culture, and economics after completing qualification exams. "Blue cards" have been put into circulation by the Republic of Turkey for professionals satisfying working conditions. ${ }^{33}$ This is an attempt to promote professional repatriation within the intellectual circles of the Diaspora.

In addition to legislative changes, in 2010, the Turkish government also created a state body for Diaspora affairs, the Department of Foreign Turks and Friendly Societies (Yurtdişi Türkler ve Akraba Topluluklar Başkanliği-YTB). This institution has already been mentioned in reference to SETA's professional repatriation activities.

Currently, YTB is the official institution responsible for the Turkish diaspora and all the issues concerning it. YTB has been working to support Turkish youth abroad through a variety of programs including Youth Bridges and Young Leaders. Since 2016, YTB has been willing to bring Turkish young scholars abroad to their homeland with the "Türkiye Internship Program". Approximately 50 institutions are participating in the YTB's "Türkiye Internship Program". This program's primary goal is to strengthen the social, cultural and economic ties between Turkish university students abroad and their homeland, as well as introducing them to the institutions and organizations of Turkey ${ }^{34}$. Therefore, the aim of this project is to help those young professionals to find their future career planning within the borders of the Turkish Republic.

The Turkish government does not fully rely on think tanks' activity for professionals' repatriation. Moreover, it is adopting laws and creating governmental agencies whose focus is on developing a good relationship between Turkey and Turkish diaspora.

As mentioned in the introduction, ORSAM is trying to be more independent from the Government in its activities. Perhaps this is the reason why the think tank has not carried out any activities for professional repatriation so far. Professional Diaspora was first involved in the think tank's programs in December 2018, only within the framework of the Middle Eastern and South African think tank's forum organized by ORSAM ${ }^{35}$. Although all of the topics discussed during the symposium were addressed to the problems of the Turkish diaspora, only 2 of those were somewhat related to the Academic diaspora strategies the Turkish state is implementing.

The following policy shows that ORSAM, trying to demonstrate its independence from the Turkish government, at the same time disrupts itself to undertake any steps towards impacting the Turkey-Turkish diaspora relationship.

\footnotetext{
33 Saatcioğlu, S. (2021). Бирюзовая карта в Турции (Turquoise cards in Turkey). https://www.antalyahomes.ru/biryuzovaya-karta-v-turtsii. (accessed August 4, 2021).

${ }_{34}$ YTB. (2016). Turkey internships. https://www.ytb.gov.tr/en/abroad-citizens/ytb-turkey-internships. (accessed August 22, 2021).

35 ORSAM. (2019). MENA think tank forum: migration and diaspora. https://orsam.org.tr/en/menathink-tank-forum-migration-and-diaspora/. (accessed August 23, 2021).
} 
As a result, the think tank only touches the issue without leaving any significant effect.

The ideological-political directions, around which the foreign and domestic policies of states are formed, play an important role in the processes taking place in the modern world. In this context, important and interesting are the components of Turkey's foreign policy to cooperate with the "Turkic world".

It is well known that, in accordance with its foreign policy strategy, Turkey mainly pursues policies aimed at unifying the Turkic states around its axis through the Parliamentary Assembly of Turkic Speaking Countries, the Turkic Council (Turkic Speaking Countries Cooperation Council) and other institutional structures. Those are not only in the form of political, but also cultural, educational and tourism agendas.

Much work is also being done in the Turkish think tanks, specialized in strategic development, to integrate and assess opportunities for cooperation between them in different Diasporas. During the last decade, several centers for conducting research, conferences and all-Turkish forums on the problems of the Turkic world have been established. Especially noteworthy is the Center for Turkish-Asian Strategic Studies. ${ }^{36}$ However, this paper is mainly focusing on the activity of think tanks SETA and ORSAM, which will be examined furthermore.

SETA's foreign policy towards the Turkish diaspora and Turkey's foreign policy towards it is once again linked to YTB's activities. Not falling behind forums organized by other think tanks, SETA also engages the Turkic diaspora by uniting it with the Turkish diaspora. The forum with the previously mentioned Balkan think tanks not only pursued the issue of professional repatriation but also the involvement of Turkic-speaking peoples living in the Balkan countries into Turkish politics. This strategy can be likened to mapping. The impression is that SETA is trying to establish friendly relations with the countries involved in the territory of the former Ottoman Empire. It is no accident that the think tank is run by the members of the Turkish Conservative Party.

In addition to engaging Turkey's foreign policy with the Turkic diaspora, SETA is pursuing an interesting strategy to draw the attention of Islamic people to Turkey and its foreign policy. The think tank organizes numerous panels on Islamophobia, ${ }^{37}$ its levels in different countries, and as all think tanks - offers possible solutions.

Hereby we see that SETA has a more significant independent influence on the integration of Turkic states into Turkey-Turkish diaspora relationship and therefore to Turkish foreign policy than repatriation. However, independence is

\footnotetext{
${ }^{36}$ See TASAM. (2013). 2nd world Turkic forum. Turkic Diaspora and Turkic world vision 2023. https://tasam.org/en/Etkinlik/133/2nd world turkic forum. (accessed August 15, 2021); TASAM. (2015). 4th World Turkic forum. Public diplomacy, media, information. Sub-themes: Public diplomacy, media, information; New perspectives for Turkic world and diasporas. https://tasam.org/en/Etkinlik/678/4th world turkic forum. (accessed August 25, 2021); TASAM. (2021). 6th world Turkic forum (2022). Future Eurasia, Turkic world and Diasporas. https://tasam.org/en/Etkinlik/16229/6th world turkic forum. (accessed August 28, 2021).

37 SETA. (2018). European Islamophobia report 2018 presentation. https://www.setav.org/etkinlikler/avrupa-islamofobi-raporu-2018-sunumu/. (accessed September 24, 2021).
} 
not complete as YTB still plays a major role in the implementation of think tank's projects. It is also noteworthy to mention that the inclusion of panels on Islamophobia in their foreign policy strategies shows how SETA's activity revolves around satisfying the ideologies of the ruling party.

ORSAM has many more projects, forums, and symposiums involving the Turkish diaspora to develop Turkey's foreign policy than SETA. Since its inception, the think tank has paid particular attention to Turkmen involvement in Turkish foreign policy as a Turkic diaspora. This can be related to the fact that ORSAM is financed by the Turkmen foundations in the Middle East for its activities.

Considering the Syrian-Turkmen community as a Turkic diaspora, ORSAM has initiated an interesting project that corresponds to the global think tank definition. The think tank has not only proposed the project but also implemented it. From the $23^{\text {rd }}$ of April to 29 ${ }^{\text {th }}$ of April 2017, Personal Development and Leadership Training school for Syrian Turkmen Youth was built. ${ }^{38}$

In 2019, ORSAM also managed to organize a non-prototype international symposium. Surprisingly, this was one of the rare occasions when YTB, which plays the role of the "Ministry of Diaspora" in Turkey, not only participated in the symposium organized by ORSAM but was also on the host list. The Symposium included 50 think tanks from 33 countries of the Middle East and South Africa. It should be noted that South Africa has never been considered as the Turkic diaspora before, and this symposium provides the Turkish government with the opportunity to expand its influence on friendly nations by including 5 African countries to the existing list. Organizers have mentioned that it is important that the representatives of the present communities to the symposium maintain their ties with the Diaspora communities in other nationstates while preserving their cultural characteristics. ${ }^{39}$ The main topics discussed during the symposium were related to migration issues, State-Diaspora relations, partnerships, etc. To conclude, the main topic of the symposium was the Diaspora.

ORSAM being independent of Government, has more success in integrating both the Turkish and Turkic diasporas into Turkey's foreign policy plans. This is mostly connected to the fact that the think tank is funded by the Turkic diaspora itself. However, it is also important to note that even ORSAM is unable to completely avoid involvement of the Government in its projects as YTB is involved in its international symposium.

Conclusion. The research has shown that as the Turkish think tanks are relatively new actors in contemporary Turkish politics they are still unable to play major roles in big political sectors such as the Diaspora. The research also showed that the type of the think tank also affects the level of independence and, therefore, the effect the think tank has on the issues concerning the Diaspora.

\footnotetext{
38 ORSAM. (2017). School for personal development and leadership for Syrian Turkmen youth. https://orsam.org.tr/tr/suriye-turkmen-gencleri-icin-kisisel-gelisim-ve-liderlik-okulu/ (accessed August 28, 2021).

39 ORSAM. (2019). MENA Think tank forum: migration and diaspora. https://orsam.org.tr/en/menathink-tank-forum-migration-and-diaspora/ (accessed August 23, 2021).
} 
SETA, for example, being a quasi-governmental think tank constantly aligns its activities with the plans and policy of YTB, which, to remind, is considered as the "Ministry of Diaspora" in Turkey. On the other hand, ORSAM, which tries to show independence from the Government is not able to carry out more wideranging activities in areas where Government agencies are heavily involved. Even the activities completely funded by the think tank itself involve and are controlled by the Turkish government with the involvement of YTB into the projects. Apart from all these, the Government in its turn takes some steps to involve the Turkish and Turkic Diasporas in its policies by establishing different laws regarding repatriation, creating councils, etc.

To finalize all the points mentioned above, we may conclude that the Turkish think tanks SETA and ORSAM affect the Turkey-Turkish diaspora relationship by organizing different panels, forums, and symposiums. However, they are not the major or the only political force to implement such policies as the sphere is not trusted to the think tanks only and different Government institutions are involved in the relationship-building/developing processes of the country. Summing up the observation of some features of the Diaspora's policy and the work done in a number of areas, we can infer that it is a relatively new phenomenon in Turkey's foreign policy and the relations between the institutions involved in it are of a horizontal nature. In fact, in order to cooperate with the Diaspora of the Turkicspeaking states and implement academic, cultural, economic, informational and other projects aimed at them, the parties strive to achieve a strategic depth of relations.

Acknowledgments: The authors would like to thank the editor and anonymous reviewers for their valuable comments and useful suggestions.

\section{References}

1. Akkuş, Ö., Durmaz, A. (2021). Tersine Göç Eğiliminin Akademik Diasporanin Verimliliği Üzerindeki Etkisi: Almanya Örneği (The effect of reverse migration tendency on the productivity of academic diaspora: The case of Germany). Uluslararasi Ekonomi ve Yenilik Dergisi (International journal of economics and innovation), 7(2), 259-276. https://doi.org/10.20979/ueyd.917786

2. Arslan, N. (2017). Beyin Göçü ve Diaspora Ağlari (Brain drain and diaspora networks). Sosyal Siyaset Konferanslari Dergisi (Journal of social policy conferences), 73, 1-33.

3. Atoyan, V. (2014). Globalization and Transformation of the Nation State. International Conference on Arts, Economics and Management (ICAEM'14), March 22-23, 2014, Dubai (UAE), 79-82. http://dx.doi.org/10.15242/ICEHM.ED0314041

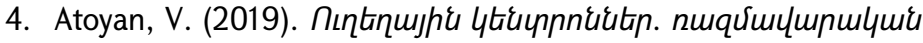
qunumumulinh quppunguling (Think Tanks: The Smithies of Strategic Ideas). Yerevan, Zangak Publishing House, 216. https://ssrn.com/abstract=3856159

5. Avatkov, V., Vidyaykin A. (2013). Деятельность аналитических центров в Турции при правлении Партии справедливости и развития (Think tanks in Turkey in the era of JDP). Вестник МГИМО (MGIMO Review of international relations), 3, 100-104. 
6. Aydin, A. (2006). The genesis of think-tank culture in Turkey: past, present and future? (Master's thesis). Middle East Technical University. Ankara.

7. Babur, M. (2021). Bir Temsil Alani Olarak Türkiye'de Düşünce Kuruluşlari (Turkey's think tanks as a sphere of representation). Afyon Kocatepe Üniversitesi Sosyal Bilimler Dergisi (Afyon Kocatepe University Journal of Social Sciences), 23(1), 1-19.

8. Baser, B. (2017). Turkey's diaspora engagement policy under the Justice and Development Party. International migration institute network blog.

https://www.migrationinstitute.org/blog/turkey2019s-diasporaengagement-policy-under-the-justice-and-development-party (accessed August 17, 2021).

9. Bayrakli, E. (2016). Diaspora politikamiz (Our diaspora policy). https://www.setav.org/diaspora-politikamiz/. (accessed June 17, 2021).

10. Bibikova, О. (2014). Турецкие иммигранты в Германии: проблемы и перспективы (Turkish immigrants in Germany: problems and prospects). Россия и мусульманский мир (Russia and the Moslem world), 9(267), 168-187.

11. Bilgili, O., Siegel, M. (2011). Understanding the changing role of the Turkish diaspora.

http://collections.unu.edu/eserv/UNU:209/wp2011-039.pdf. (accessed August 5, 2021).

12. Chulkovskaya, Е. (2014). Турецкая диаспора Германии: между Анкарой и Берлином (Turkish diaspora in Germany: between Ankara and Berlin). Moscow. Middle East Institute.

13. DEIK. (2016). 2 Dünya Türk Iş Konseyi Dünya Türk Girişimciler Kurultayi $\left(2^{\text {nd }}\right.$ world Turkish Business Council World Turkish Entrepreneurs Congress). https://www.deik.org.tr/uploads/dtik-sonuc-raporu 11-4-2016.pdf (accessed August 5, 2021)

14. Erder, S. (2002). Новые тенденции международной миграции в Турции (New trends in international migration in Turkey). http://www.demoscope.ru/weekly/2002/079/analit04.php. (accessed June 28, 2021).

15. Hurriyet Daily News. (2012). Council mobilizing the Turkish diaspora. https://www. hurriyetdailynews.com/council-mobilizing-theturkish-diaspora-30022 (accessed August 25, 2021).

16. Gehrke, L., Pluim, M. (2017). The Era of Migration - the Next 25 Years. https://www.icmpd.org/news-centre/news-detail/the-era-ofmigration-the-next-25-years-by-lukas-gehrke-and-martijn-pluim/. (accessed August 1, 2021).

17. Kalça, A., Durmaz, A. (2010). Outside the homeland of the Turks economic potential of the Diaspora. 2nd international symposium on sustainable development, June 8-9, 2010, Sarajevo (Bosnia and Herzegovina).

https://omeka.ibu.edu.ba/files/original/252225c345f542fb52d0e4b3 a4bb26e9.pdf (accessed July 15, 2021).

18. Karabulut, N. (2019). Impact capacity of think tanks in Turkey (Master's thesis). Necmettin Erbakan University. Konya. 
19. Karpuzcu, T. (2018). L'influence des elites de think-tank sur la formation de la politique exterieure de la Turquie entre 2010-2016 (The influence of think-tank elites on the formation of Turkey's foreign policy between 2010-2016). Universite Yeditepe.

20. Kizyukov, S. (2006). Внешнеполитические концепции республиканской Турции (Foreign policy concepts of Republican Turkey). Bishkek.

21. Ksendzik, N. (1991). Турецкая трудовая иммиграция в странах Западной Европы (70-80-е г2.) (Turkish labor immigration in Western Europe (70-80s)). Kiev.

22. Masumova, N. (2009). Миграция турецкой рабочей силы в страны Западной Европы (Turkish Labor Migration to Western Europe). Мировое и национальное хозяйство (World and national economy), 2(9), 55-67.

23. Mendizabal, E. (2017). How change happens and what can think tanks do about it? https://onthinktanks.org/articles/how-changehappens-and-what-can-think-tanks-do-about-it/. (accessed August 28, 2021).

24. ORSAM. (2017). School for personal development and leadership for Syrian Turkmen youth. https://orsam.org.tr/tr/suriye-turkmengencleri-icin-kisisel-gelisim-ve-liderlik-okulul. (accessed August 28, 2021).

25. ORSAM. (2019). MENA think tank forum: migration and diaspora. https://orsam.org.tr/en/mena-think-tank-forum-migration-anddiaspora/. (accessed August 23, 2021).

26. Outzen, R.H., Schwing, R. (2016). Supporting democracy in Erdogan's Turkey: The role of think tanks. In Strategic forum. 292, 1-15. National defense university press.

27. Saatcioğlu, S. (2021). Бирюзовая карта в Турции (Turquoise cards in Turkey). https://www.antalyahomes.ru/biryuzovaya-karta-v-turtsii. (accessed August 4, 2021).

28. SETA. (2018). European Islamophobia report 2018 presentation. https://www.setav.org/etkinlikler/avrupa-islamofobi-raporu-2018sunumu/. (accessed September 24, 2021).

29. Simavoryan, A. (2012). Anıpphujh nıntquujhu ltiuunnnüutitph

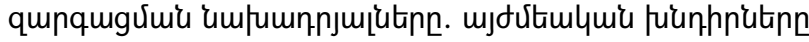
(Preconditions of the development of think tanks in Turkey: Modern

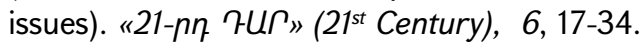

https://doi.org/10.5281/zenodo.5546165

30. Simavoryan, A. (2015). Strategic research centers in Turkey. "Globus" analytical bulletin, 5, 13-21. https://doi.org/10.5281/zenodo.5572698

31. Simavoryan, A. (2019). On some of the issues of expertise centers in Turkey. Orbeli center. http://dx.doi.org/10.2139/ssrn.3891456

32. Suleimanov, А. (2010). Центры стратегических исследований внешней политики Турецкой Республики: общая характеристика и этапы функционирования (The centers of strategic research of foreign policy of Turkish Republic: The general characteristic and stages of functioning). Вестник РУДН. Серия: Политология (RUDN Journal of Political Science), 4. 61-67.

33. TASAM. (2013). 2nd world Turkic forum. Turkic diaspora and Turkic world vision 2023. 
https://tasam.org/en/Etkinlik/133/2nd_world_turkic_forum. (accessed August 15, 2021).

34. TASAM. (2015). 4th world Turkic Forum. Public diplomacy, media, information. Sub-themes: public diplomacy, media, information; new perspectives for Turkic world and diasporas. https://tasam.org/en Etkinlik/678/4th world turkic forum. (accessed August 25, 2021).

35. TASAM. (2016). 5th world Turkic forum. Strategic communication: reference values, institutions. https://tasam.org/Files/Etkinlik/File VizyonBelgesi/DTF5 Vizyon TR pdf 0ba46c0f-5d28-4d14-b18b83aaf0f1294f.pdf. (accessed August 27, 2021).

36. TASAM. (2021). 6th world Turkic forum (2022). Future Eurasia, Turkic world and diasporas. https://tasam.org/en/Etkinlik/16229/6th_world_turkic_forum. (accessed August 28, 2021).

37. TOBB. (2014). Türk Diasporasi "Dünya Şehir Aği” kuruyor (The Turkish diaspora is establishing a "world city network"). https://tobb.org.tr /Sayfalar/Detay.php?rid=19696\&lst=MansetListesi (accessed August 30, 2021).

38. Toktaş, Ş., Aras, B. (2012). National security culture in Turkey: A qualitative study on think tanks. Bilig, 61, 245-264.

39. Uygun, A. (2012). Yurt Dişindaki Türk Bilim İnsanlari Kurultayi ilk kez İstanbul'da yapildi. Telepati E-dergisi, Ağustos, 203 (The congress of Turkish scientists abroad was held in Istanbul for the first time. "Telepati”, E-journal. 203).

40. YTB. (2015). https://www.ytb.gov.tr/haberler/balkan-dusuncekuruluslari -ankarada-bulustu. (accessed August 8, 2021).

41. YTB. (2016). https://www.ytb.gov.tr/haberler/balkan-dusuncekuruluslari -kosovada-bulustu. (accessed August 15, 2021).

42. YTB. (2016). Turkey internships. https://www.ytb.gov.tr/en/abroadcitizens/ytb-turkey-internships. (accessed August 22, 2021).

43. YTB. Turkish and education. https://www.ytb.gov.tr/en/abroadcitizens/turkish-and-education. (accessed August 22, 2021).

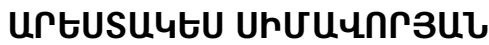

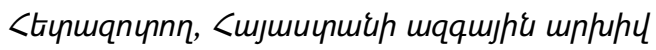

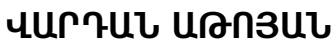

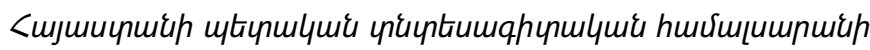

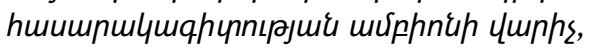

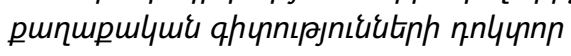

\section{unUt UhuUunrзu乙}

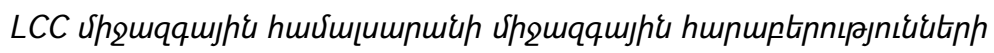

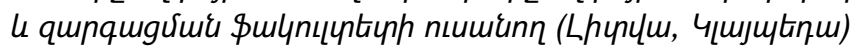

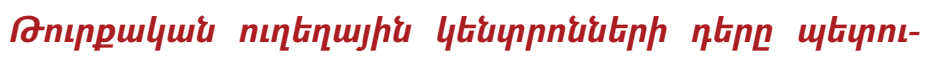

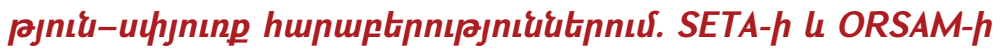

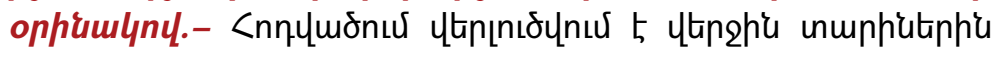

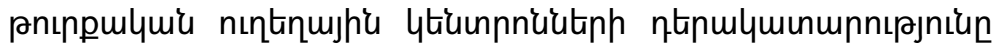

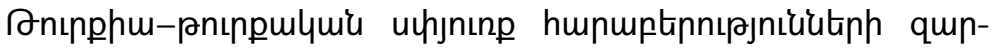




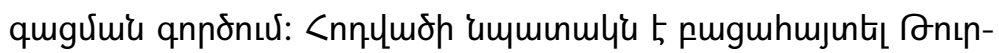

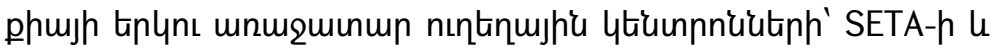

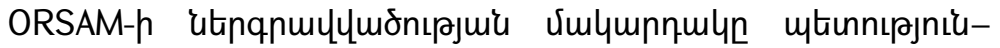

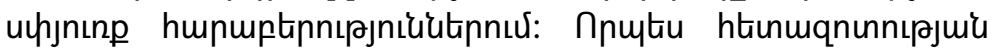

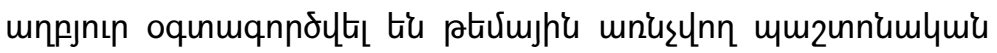

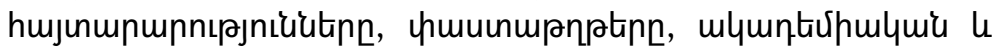

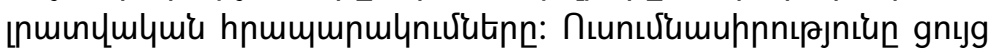

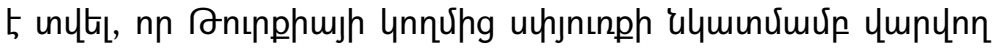

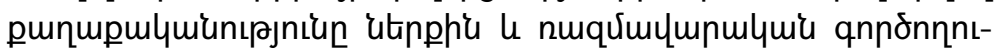

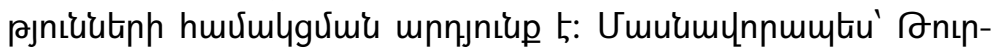

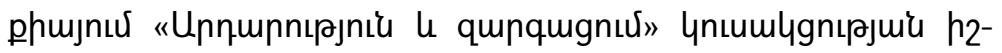

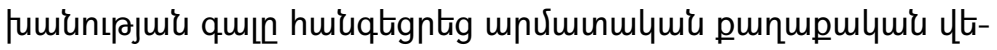

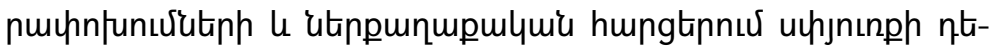

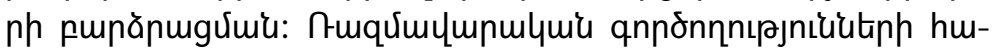

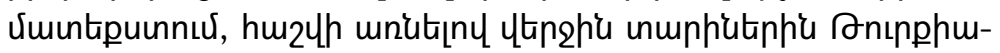

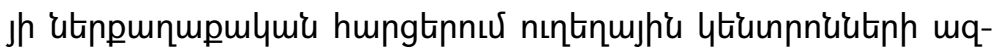

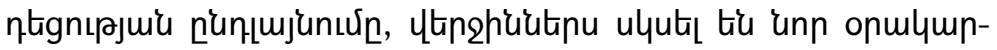

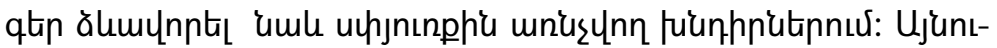

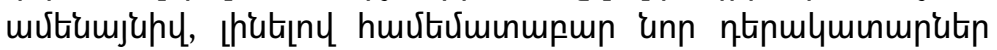

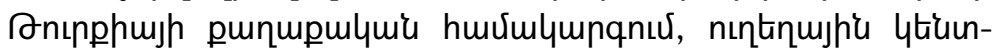

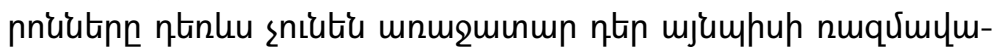

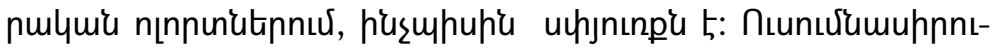

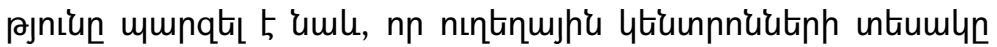

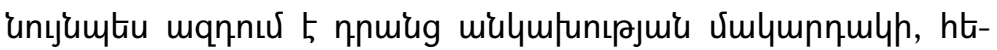

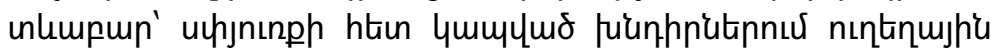

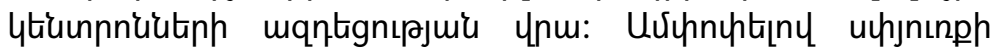

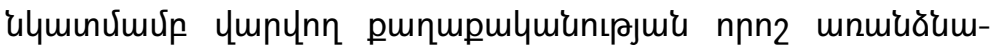

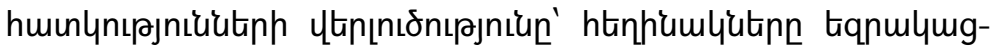

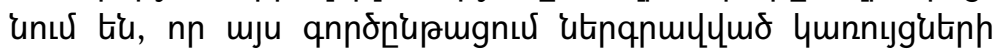

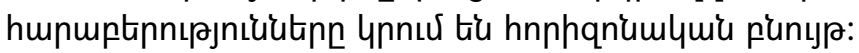

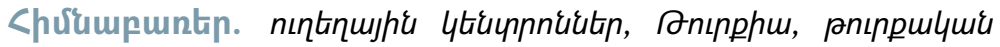

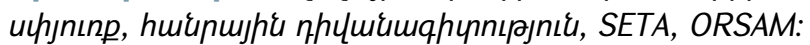

JEL: J24, Z00

DOI: 10.52174/1829-0280_2021_5_143 


\section{AРЕСТАКЕС СИМАВОРЯН}

Научный сотрудник, Начиональный архив Армении

\section{ВАРДАН АТОЯН}

Доктор политических наук, заведующий кафедрой общественных наук

Армянского государственного экономического университета

\section{СОСЕ СИМАВОРЯН}

Студентка факультета международных отношений и развития, Международный университет LCC, Литва, Клайпеда

Роль турецких мозговых центров в отношениях между государством и диаспорой: на примере SETA и ORSAM.- В статье анализируется роль турецких мозговых центров в деле развития отношений между Турцией и турецкой диаспорой в последние годы. Цель статьи - выявить степень вовлеченности двух ведущих мозговых центров Турции, SETA и ORSAM, в отношениях между государством и диаспорой. Источниками исследования послужили официальные заявления, документы, публикации в научных журналах и средствах массовой информации. Исследование показало, что политика Турции в отношении диаспоры является результатом сочетания внутренних и стратегических действий. В частности, приход к власти Партии справедливости и развития в Турции привел к радикальным политическим трансформациям и повышению роли диаспоры во внутригосударственных вопросах. В контексте стратегических действий в последние годы по мере роста воздействия мозговых центров на внутреннюю политику Турции последние начали формировать новые повестки в вопросах, связанных с диаспорой. Тем не менее, будучи относительно молодыми игроками в современной турецкой политике, мозговые центры пока не в состоянии играть ведущую роль в стратегических вопросах, касающихся диаспоры. Исследование также показало, что тип мозгового центра также влияет на уровень независимости последнего и, следовательно, на степень воздействия мозгового центра на вопросы, касающиеся диаспоры. Резюмируя анализ некоторых особенностей политики по вопросам, касающимся диаспоры, авторы приходят к выводу, что отношения между структурами, вовлеченными в этот процесс, носят горизонтальный характер.

Ключевые слова: мозговые центры, Турция, турецкая диаспора, публичная дипломатия, SETA, ORSAM.

JEL: J24, ZO0

DOI: 10.52174/1829-0280_2021_5_143 